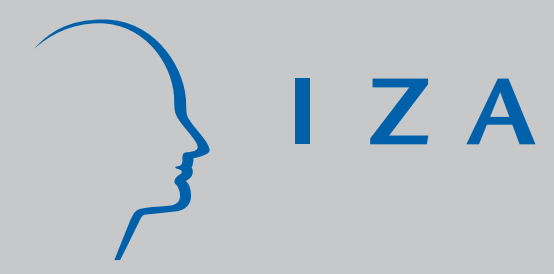

IZADP No. 1925

The Social Impact of Globalization in the Developing Countries

Eddy Lee

Marco Vivarelli

J anuary 2006 


\title{
The Social Impact of Globalization in the Developing Countries
}

\author{
Eddy Lee \\ ILO, Geneva
}

\author{
Marco Vivarelli \\ Catholic University of Piacenza, \\ Max Planck Institute of Economics, Jena, \\ CSGR, University of Warwick and IZA Bonn
}

\section{Discussion Paper No. 1925 \\ January 2006}

\author{
IZA \\ P.O. Box 7240 \\ 53072 Bonn \\ Germany \\ Phone: +49-228-3894-0 \\ Fax: +49-228-3894-180 \\ Email: iza@iza.org
}

\begin{abstract}
Any opinions expressed here are those of the author(s) and not those of the institute. Research disseminated by IZA may include views on policy, but the institute itself takes no institutional policy positions.

The Institute for the Study of Labor (IZA) in Bonn is a local and virtual international research center and a place of communication between science, politics and business. IZA is an independent nonprofit company supported by Deutsche Post World Net. The center is associated with the University of Bonn and offers a stimulating research environment through its research networks, research support, and visitors and doctoral programs. IZA engages in (i) original and internationally competitive research in all fields of labor economics, (ii) development of policy concepts, and (iii) dissemination of research results and concepts to the interested public.
\end{abstract}

IZA Discussion Papers often represent preliminary work and are circulated to encourage discussion. Citation of such a paper should account for its provisional character. A revised version may be available directly from the author. 
IZA Discussion Paper No. 1925

January 2006

\section{ABSTRACT \\ The Social Impact of Globalization in the Developing Countries}

In this paper an ex-post measurable definition of globalization has been used, namely increasing trade openness and FDI. A general result is that the optimistic HeckscherOhlin/Stolper-Samuelson predictions do not apply, that is neither employment creation nor the decrease in within-country inequality are automatically assured by increasing trade and FDI. The other main findings of the paper are that: 1) the employment effect can be very diverse in different areas of the world, giving raise to concentration and marginalisation phenomena; 2) increasing trade and FDI do not emerge as the main culprits of increasing within-country income inequality in DCs, although some evidence emerges that import of capital goods may imply an increase in inequality via skill-biased technological change; 3)increasing trade seems to foster economic growth and absolute poverty alleviation, although some important counter-examples emerge.

JEL Classification: F02, O1

Keywords: trade, FDI, employment, poverty, within-country income inequality

Corresponding author:

Marco Vivarelli

Facoltà di Economia

Università Cattolica

Via Emilia Parmense 84

I-29100 Piacenza

Italy

Email: marco.vivarelli@unicatt.it 


\section{Introduction}

This paper is one of the outcomes of a four-years economic research programme (20012005), funded by the Department for International Development (DFID) of the UK and developed at the International Labour Office (International Policy Group). The general aim of the project is to fill a gap in understanding - both theoretical and empirical - the impact of globalization.

Since the '80s, the world economy has become increasingly "connected" and "integrated"; on the one hand the decreasing transportation costs and the diffusion of Information and Communication Technologies have implied a fast downgrading of the concept of "distance", while - on the other hand - gross trade, Foreign Direct Investment (FDI), capital flows and technology transfers have risen significantly. In most countries, the current wave of "globalization" has been accompanied by increasing concern about its impact in terms of employment and income distribution.

Whatever definitions and indicators are chosen (see next section), the current debate is characterized by an acrimonious dispute between advocates and critics of globalization. While this is true even as regards the employment and income distribution effects within the developed world, positions diverge even more sharply over the impact on Developing Countries (DCs). For instance, the optimists underline the link between increasing trade and economic growth and then they conclude that trade is good for growth and growth is good for the poor (both in terms of job creation and poverty alleviation). In contrast, the pessimists show that globalization is quite uneven in its impact and gives rise to negative counter-effects on the previously protected sectors, the marginalisation of entire regions of the world economy and possible increases in withincountry income inequality (WCII). Another example of this kind of diversity of opinions is the debate about poverty indicators: supporters of globalization underline the fact that worldwide absolute poverty has decreased over the last two decades, while critics of globalization show that this result is almost entirely due to statistical artefacts and to the fast growth of China, while absolute poverty has increased in many DCs and relative poverty has increased in the majority of countries. 
The following sections will try to go deeper into these topics and provide some theoretical and empirical answers to the question of whether globalization is good for employment, poverty alleviation and income redistribution within the DCs. In more detail, the rest of the paper is organized as follows: in Section 2 some definitions and methodological choices will be presented; in the next three sections recent theoretical and empirical results will be critically discussed and compared with regard respectively to the impact of globalization on employment, WCII and poverty in DCs, while the concluding Section 6 will summarize the main findings and suggest some policy implications.

\section{Definition and methodology}

"Globalization” is currently a popular and controversial issue, though often remaining a loose and poorly-defined concept. Sometimes too comprehensively, the term is used to encompass increases in trade and liberalization policies as well as reductions in transportation costs and technology transfer. As far as its impact is concerned, discussion of globalization tends to consider simultaneously its effects on economic growth, employment and income distribution - often without distinguishing betweencountries and within-country inequalities - and other social impacts such as opportunities for poverty alleviation, human and labour rights, environmental consequences and so on. Moreover, the debate is often confused from a methodological point of view by the interactions between history, economics, political science and other social sciences. Partially as a consequence of the lack of clear definitions and methodological choices, the current debate is characterized by an harsh divide between the supporters and the opponents of globalization, where both groups appear to be ideologically committed and tend to exploit anecdotes (successfully or unsuccessfully respectively), rather than sound, comprehensive empirical evidence to support their cause .

Since the debate appears quite confused and the issues overlapping, one of the aims of this contribution is to select some precisely-defined topics and to give an account of 
theories and applied approaches which have really contributed to the understanding of the social impact of globalization in developing countries (DCs). With this purpose in mind, it is therefore important to clarify the limitations of the discussion put forward in the following sections.

\section{Definition.}

An ex-post measurable and objective definition of globalization has been used, namely increasing trade openness and FDI. The purpose is to discuss whether the actual increase in trade and FDI inflows is favouring or damaging DCs engaging in globalization. In this context, we will not address liberalization policies; these are ex-ante proposals which may be announced and not implemented or implemented but not effective. When evaluating the effect of globalization, what is really important is not the impact of (often ineffective) policies but the consequences of the actual increase in measurable globalization indexes such as trade openness and FDI. An important limitation of the subsequent analysis is that some aspects of globalization will not be treated (see for instance migration) or only marginally discussed (see for instance financial and portfolio flows).

Countries and period.

We will only discuss the consequences of globalization (as defined above ) on DCs over the last two decades. Although there is much wider economic literature available on the impact of globalization in developed countries, here we will only focus on DCs .

\section{Methodology.}

While this subject may also be fruitfully studied from a historical, sociological, demographical or political viewpoint, here the adopted methodology will be only economic, with particular attention devoted to the applied approaches.

Scope.

Only some particular aspects of the social consequences of globalization in DCs will be treated, namely the impact of increasing trade and FDI upon domestic employment, within-country income inequality (WCII) and poverty reduction. 
Given this general framework, further and more detailed purposes of this paper are as follows:

1) to provide a comprehensive discussion of the recent theoretical and empirical economic literature investigating the three-fold impact of globalization mentioned above;

2) to address the relevant research questions emerging from the existing literature, namely: a) What is likely to happen to local employment and income distribution when a DC chooses to open (or becomes exposed) to globalization? b) Which are the channels through which trade and FDI affect employment, within-country income distribution and poverty reduction? c) What is the role of the level of development and of the institutional framework of a given DC?

3) to derive possible policy implications, useful for national and international policy-makers targeting the social consequences of globalization in DCs.

\section{Globalization and employment.}

According to the theory of the relative comparative advantages, both trade and FDI should take advantage of the abundance of labour in DCs and so trigger a trend of specialization in domestic labour-intensive activities and so involve an expansion in local employment.

However, contrary to this Heckscher-Ohlin (HO) prediction, the analysis of the recent literature supports the conclusion that the employment impact of increasing trade is not necessarily positive for a developing country. In particular, a relaxation of the hypothesis of homogeneous production functions across different countries allows for either the possibility of multiple equilibria (Grossman and Helpman, 1991), or for quite differentiated employment trends in the evolutionary “catching-up” models (Fagerberg, 
1988 and 1994; Dosi et al., 1990; Cimoli and Dosi, 1995; Verspagen and Wakelin, 1997; Targetti and Foti, 1997; Montobbio and Rampa, 2005). In fact, when "total factor productivity” increases in the DCs as a consequence of globalization, the employment enhancing competitive effect has to be compared with the direct labour-saving effect of the imported technologies (see Haddad and Harrison, 1993; Coe et al., 1997; Aitken and Harrison, 1999; Kathuria, 2001). In other words, in a developing country, the final employment impact of increasing trade depends on the interaction between productivity growth and output growth both in traded goods sectors and in non-traded sectors. The final outcome cannot be assessed a priori for different reasons. On the one hand, export may involve a demand-led economic and employment growth, but - on the other hand import may displace previously protected domestic firms, inducing labour redundancy. Moreover, in the presence of supply constraints (lack of infrastructures, scarcity of skilled labour, under investment, inefficient labour market), even in the exporting sectors productivity growth may exceed output growth, to the detriment of job creation. Finally, domestic sheltered sectors (such as agriculture, public administration, construction, non-traded service) may act as labour sinks, often implying hidden unemployment and underemployment in the informal labour market (see Fosu, 2004 and Reddy, 2004).

Shifting our focus from trade to FDI inflows, when a developing country opens its borders to foreign capital, FDIs generate positive employment impacts both directly and indirectly through job creation within suppliers and retailers and also a tertiary employment effect through generating additional incomes and so increasing aggregate demand (see Lall, 2004). Yet, all these positive employment effects of "greenfield” FDI have to be compared with the possible crowding-out of non-competitive and previously sheltered domestic firms (implying bankruptcies and job losses); with the possible labour-saving effects of the new technologies brought about by multinational firms; and with the possible reduction in employment associated with FDI operating through Mergers and Acquisitions (M\&A).

In fact, both imports and inward FDI may imply a “crowding out" of domestic production (especially formerly protected nascent industries; think, for instance, to the 
case of large urban state-owned firms in China, see Rawski, 2002; see also Aitken and Harrison,1999).

This job displacement effect can be further amplified when FDI inflows are accompanied by financial liberalization and consequent increases in the interest rate, in turn leading to shrinking domestic investments (see Berg and Taylor, 2001).

Since the overall employment impact of trade and FDI is uncertain from a theoretical point of view, it is important to collect data on these relationships and to empirically investigate the direct and indirect effects of globalization on the domestic employment of a globalizing DC.

Matusz and Tarr (1999) survey the studies carried out before 1995 on the impact of globalization on employment in DCs. Comparing the level of employment before and after trade liberalization the authors conclude that trade and FDI liberalization has been beneficial for labour except in the transition countries of Eastern Europe. Ghose (2000 and 2003) analyses the relationship between trade liberalization and manufacturing employment. He highlights that - although increasing trade and FDI have been relevant only in a small bunch of newly industrialized countries - for those countries the growth of trade in manufactured products has implied a large positive effect on manufacturing employment. More evidence has been collected at the national level mostly for the manufacturing sector. It draws a contrasted picture of the effect of globalization. In successfully integrating DCs, the employment effects of trade liberalization has been mixed (mostly negative) in Latin America (see Rama, 1994; Revenga, 1997; Levinsohn, 1999; ILO, 2002; Cimoli and Katz, 2003) whereas they seem globally positive in Asian countries (see Lee, 1996; Orbeta, 2002).

Indeed, the theoretical issues and the empirical evidence discussed in Lee and Vivarelli (2004) lead to the conclusion that the employment impact of trade and FDI is country and sector specific and that the HO theorem is actually rejected in most cases.

For instance, Lall (2004) observes that - while there is a clear evidence that several DCs have exhibited export and employment growth as a consequence of opening to trade and FDI (see also UNIDO, 2002) - doubts can be cast about the belief that globalization should always benefit employment growth within a DC; indeed, different "national 
absorptive capacities” (or “social capabilities”, see Abramovitz, 1986 and 1989) - in terms of institutional setting, labour skills, technological capabilities and competitiveness of domestic firms - can amplify the positive employment impact of globalization, while institutional mismatches between the market, the organisations and the government (see Perez, 1983; Shafaeddin, 2005) and lack of local capabilities can severely jeopardize the potential for economic and employment growth (see also Basu and Weil, 1998).

In this framework, Gros (2004) notes that opening to trade implies both an increase in value added and in labour productivity and so that the employment impact cannot be predicted a priori; empirically, the best results in terms of employment growth happen to be within the "non globalizing” DCs (basically because of a lack of any improvement in labour productivity) and in the "slowly globalizing" DCs which are characterised by a labour friendly balance between output and productivity trends.

Finally, Spiezia (2004) studies the employment impact of trade on the manufacturing sector. By comparing labour intensities of exported, imported and non-trade goods the author concludes that in 21 out of 39 sampled DCs an increase in the volume of trade resulted in an increase in employment; however, in the second group of 18 countries, increased integration produced a reduction in employment (in contrast with the HO theorem). As far as FDI is concerned, the author finds out that the impact of FDI on employment is increasing with per-capita income, resulting not significant for lowincome DCs.

\section{Globalization and within-country income inequality.}

On the one hand, the Stolper-Samuelson (SS) theorem predicts that both trade and FDI should take advantage of the abundance of low-skilled labour in DCs and so imply an increasing demand for domestic low skilled labour and hence decreasing within-country wage dispersion and income inequality (see Stolper and Samuelson, 1941; for a recent 
reappraisal of the possible equalizing effect of trade in newly industrialized countries, see Wood, 1994 and 1997; for a critical view, see Milanovic, 2002a).

Some important theoretical critiques can be addressed to the SS theorem .

First, is the theorem valid in a global sense or in relation to the so-called "cones of diversification” (see Davis, 1996, a cone of diversification being a group of countries characterised by similar endowment proportions, very similar production functions and supplying the same range of goods)? If SS theorem is valid not in relation to the world economy but in relation to a specific cone of diversification, it could be the case that countries abundant in unskilled labour in a global context are abundant in capital and skilled labour in comparison with some other country in the same cone; if such is the case, the SS theorem might have very different distributional consequences from those one would anticipate on the basis of a simplistic North-South interpretation of the theorem (for instance, in Mexico the equalizing effect of trade and FDI with the USA may be more than compensated by the dis-equalizing effect of competition by China and other newly industrialized Asian countries; see also Wood, 1997 and Wood and Ridao-Cano, 1999).

Second, Feenstra-Hanson's (1996 and 1997) model points out that what is unskillintensive in a developed country may be skill-intensive in terms of the labour market of the recipient DC; accordingly, shifting production from developed towards developing countries (both through FDI and import/export trade relationships) may imply increasing inequality both in the former and in the latter. For instance, outsourcing of production through FDI from the U.S. to Mexico implies that plants which were relatively intensive in unskilled labour in the U.S. would be relatively skill-intensive in Mexico (with a higher ratio of skilled/unskilled labour than domestic plants), thus raising relative wages and income inequality in both countries (see also Zhu and Trefler, 2001).

Third, the latter increasing inequality effect may be amplified by a possible "skillbiased" nature of technologies embodied both in FDIs (see Findlay, 1978; Wang and Blomstrom, 1992) and in importation of capital goods. Indeed, capital equipment and intermediate goods constitute the majority of increasing imports by DCs following 
liberalisation (see Acemoglu, 1998; O’Connor and Lunati, 1999). For sake of clarity, we can look separately at FDI and importation.

If we think about FDI as a vehicle of new technologies, in addition to the direct effect, there are different channels through which skilled-biased innovation spill over from foreign to local firms: the demonstration effect (local firms adopt new technologies through imitation and reverse engineering, see Piva, 2003); the vertical spillovers (backward and forward linkages lead to intra and inter-industry technology upgrading: see Saggi, 1999); labour turnover and spin-offs (workers trained in foreign owned firms may transfer important know-how to local firms by switching employers or by startingup their own business, see Kinoshita, 2000); and the competition effect (technology upgrading in local firms becomes necessary because of competitive pressures from foreign firms, see Bayoumi et al., 1999).

More than other imports, imports of capital goods, - embodying technological innovations - are important both because of the role they play in contributing to capital upgrading and more generally to economic growth of DCs (Xu and Wang, 2000; Eaton and Kortum, 2001; Mazumdar, 2001), and because they originate the so-called "skillenhancing trade”, (see Robbins, 1996 and 2002; Barba Navaretti et al., 1998; Berman and Machin, 2000 and 2004; Vivarelli, 2004). In fact, even without necessarily assuming that developed countries transfer their "best" technologies to the DCs, it is quite reasonable to expect that transferred technologies are relatively skill-intensive, i.e. more skill-intensive than those in use domestically before trade and FDI liberalization. If such is the case, openness - via technology - should imply a counter-effect to the SS theorem prediction, namely an increase in the demand for skilled labour, an increase in wage dispersion and so an increase in income inequality.

Finally, globalization is often coupled with market-oriented policy reforms within the globalizing DCs (such as the liberalization of the domestic labour market or the privatisation of previously state-owned firms; see Lee, 2000; Easterly, 2001; Stiglitz, 2002) which often imply possible increases in WCII (Rodrik, 2000; Milanovic, 2003).

Hence, on the theoretical side, relaxing the HO hypothesis of technological homogeneity, and allowing for capital deepening and skill-biased technological change 
(SBTC), opens the way to an important possible counter-effect in terms of the distributional impact of globalization, and so the theoretical prediction ceases to be univocal and becomes open to different outcomes depending on the relative importance of the determinants discussed so far.

On the empirical side and starting from simple correlation analyses, both Bowles (2001) and Dollar and Kraay (2001b) do not find any significant correlation between changes in openness and changes in inequality. Turning the attention to more sophisticated econometric analyses, Edwards (1997) does not find any evidence linking trade liberalization to increases in inequality; Higgins and Williamson (1999) - using a framework based on the unconditional Kuznets' curve - fail to find any significant relationship between economic openness and inequality; Spilimbergo et al. (1999) find that trade openness has a positive impact on income inequality in skill-abundant countries, but when they limit the analysis to DCs, they fail to find any significant relationship between trade and inequality; Ravallion (2001) finds no significant effect of exports as a share of GDP on Gini index changes across 50 countries (both developed and developing countries).

However, Birchenall (2001) concludes that, in the case of Colombia, liberalization interpreted as a skill-biased technological change induced wage inequality, polarization and higher labour mobility. Pavcnik et al. (2003) show that trade reform in Brazil has contributed to the growing skill-premium through SBTC instigated by increased foreign competition (even though the overall effect on wage differentials is relatively small). Finally, Vivarelli (2004) does not find any significant distributional effect of trade openness and FDI inflows; however, in his study some evidence emerges that, in the early stages of openness to trade, importation may imply an increase in WCII (possibly via SBTC).

The main common conclusion of these empirical studies is that the popular idea that greater economic integration across countries is associated with an increase in inequality within DCs is not necessarily in contrast with theoretical considerations, but it cannot be significantly supported by available recent empirical evidence. As stated by Cornia (2004) globalization in se' does not emerge as the main culprit of the current 
increase of WCII in DCs. Yet, recent evidence is consistent with the hypothesis that the diffusion of SBTC from richer to developing countries may imply - at least temporarily - an increase in within-country inequality.

\section{Globalization and poverty alleviation}

As far as poverty reduction is concerned, trade and FDI are supposed to be beneficial to a DC’s economic growth (see Collier and Dollar, 2002; for a much more critical point of view, see Rodriguez and Rodrik, 1999) and so - given the expected overall neutrality in terms of their impact on income distribution (see Section 4) - globalization should be a way to achieve poverty reduction.

Indeed, most DCs experienced a significant reduction in the proportion of their population living below the poverty line, including fast globalizing countries like China, India, Vietnam. Conversely, many slow globalizers in the Sub-Saharan Africa registered an opposite trend.

While the apologists of globalization support the view that current trends clearly indicate a decreasing global inequality (Sala-i-Martin, 2002), the critics show that this result mainly depend on the exceptional growth of China, while absolute poverty has increased in SSA and relative poverty (inequality) has increased in the majority of countries (Milanovic 2002b; Reddy and Pogge, 2002).

On the theoretical side, economic growth is not the only vehicle through which globalization can affect poverty levels, as broadly discussed by Winters et al. (2004). In fact, globalization deeply influences labour productivity (and this may imply higher wages on the one hand but job losses on the other hand); the demand for skills (with a possible redundancy of low skilled people concentrated below the poverty line, see also previous Section 4); the need for macroeconomic stability (since stability implies low inflation, trade should affect the poor positively because the poor tend to be hardest hit by increasing inflation, see Bhagwati and Srinivasan, 2002; however, liberalization may 
also involve cautious and restrictive macroeconomic policies with an opposite effect, see Langmore, 2004); relative prices (with possible adverse or positive effects in terms of purchasing power of poor households depending on the basket of tariffs reductions and on the changes in the terms of trade); relative competitiveness of domestic firms (possibly crowded-out by more efficient multinationals), government revenues and expenditures, etc. On the whole, it is true that globalization aids economic growth and that economic growth aids poverty reduction, but not unconditionally: the final outcome in terms of poverty reduction can be actually either amplified or diminished (even cancelled) by the complementary economic factors and policies which are part of the game.

To better understand the issue, it is also important to distinguish between trade and FDI on the one hand and financial liberalization on the other hand. While increasing trade and FDIs seem to be associated with increasing economic growth and absolute poverty alleviation (although conditional on the occurrence of many complementary events), poverty can rise rapidly in the wake of increased vulnerability, occurrence of generalised economic crises and contagion of "innocent victims" which can all be related to fast financial liberalization (see Lee, 1998; Cornia, 2004; Taylor, 2004). Hence, the liberalization of capital accounts may counterbalance the poverty alleviation effect of trade and FDI and surely be correlated with possible increases in income inequality (see Taylor, 2004; Santarelli and Figini, 2004; for an opposite view underlining the long-run welfare gains associated with financial liberalization, see Kaminsky and Schmukler, 2003).

To conclude, nothing can assure that the relationship between globalization and poverty alleviation has a 1 to 1 nature as implied - for instance, - by the optimistic slogan by Dollar and Kray (2001a and 2001b) when they state that "trade is good for growth, growth is good for the poor and so trade is good for the poor".

Focusing on the empirical studies, the above mentioned Dollar and Kraay (2001a and 2001b) classify countries into globalizers and non-globalizers according to their performance in raising their trade openness (export + import over GDP) and show that the former group has experienced higher growth rates during the period 1977-97. Then 
they show that the incomes of the poor rise proportionally with average incomes and that globalization does not have any systematic effect on domestic income distribution. They therefore conclude that growth is good for the poor. A summary of the most pertinent criticisms of these papers can be found in Rodrik (2000): the author does not agree with Dollar and Kraay's exogenous definition of globalizers and challenges Dollar and Kraay's arbitrary exclusion of some countries and their use of different base years moving from one country to another. Replicating their empirical exercise, Rodrik finds no support for the hypothesis that globalizers do significantly better in terms of economic growth.

Much more cautious conclusions have been derived by Ravallion (2001) who points out that microeconomic and country-specific researches are needed to understand why some poor people are able to take up the opportunities offered by a globalizing developing economy while others not.

Finally, UNCTAD (2002) report on low-income developing countries stresses that the current conventional wisdom that persistent poverty in LDCs is mainly due to their low level of trade integration is too simplistic; indeed the characteristics of trade integration are more important than its intensity. In particular, it is underlined that completely different paths in poverty are exhibited by non-oil primary commodity exporters (in which poverty has increased) and by manufacturer exporters, which generally display a trend towards poverty alleviation.

Thus, the overall conclusion by Winters (2000) sounds particularly wise: while trade liberalization is generally found to increase economic opportunities and potentialities for DCs, it is absurd to think that globalization never pushes anyone into poverty, if any because the poor are so heterogeneous within a country and because poor countries differ so much among themselves.

Using data from 120 DCs, Santarelli and Figini (2004 and 2005) have been able to show that:

1) trade openness helps reducing absolute poverty, measured as people living below the poverty lines; 
2) FDI flows and especially financial liberalization seems to be detrimental for poverty alleviation, although the relationship is only barely significant;

3) there is no significant relationship between trade or FDI and relative poverty, measured as people below the $50 \%$ of the mean income (this result is consistent with what discussed in the previous Section 4).

\section{Conclusions and policy implications}

In Section 2, we posed some general questions to which the following discussion aimed to give analytical and empirical answers.

1) What is likely to happen to local employment and income distribution when a DC chooses to open (or becomes exposed) to globalization?

As is obvious from the discussion in the previous sections, both the theory and the empirical evidence did not give us black and white, clear-cut results, but rather nuanced research outcomes.

If one is to be found, a general result is that the optimistic HO/SS predictions do not apply to the current wave of globalization; indeed, neither employment creation nor the decrease in within-country inequality are automatically assured by increasing trade and FDI. In contrast, the employment effect can be very diverse in different areas of the world, giving raise to concentration and marginalisation phenomena, with the scope for enhancing the "absorptive capacity" of a given socio-institutional system which is quite large.

In more detail, the employment impact depends on the initial labour-intensity, the output effect and the productivity effect characterizing traded goods and non traded goods sectors. According to the values of these three parameters and to the magnitude of possible constraints in the supply of capital, infrastructure and skilled labour, very 
different results in terms of job creation can emerge. Very similar arguments apply to the employment effects of FDI inflows.

As far as income distribution is concerned, while SS's theorem definitely does not apply, it is also true that increasing trade and FDI do not emerge as the main culprits of increasing within-country income inequality in DCs. However, some evidence emerges that, in the early stages of openness to trade, import of capital goods may imply an increase in within-country inequality via SBTC.

Finally, increasing trade seems to foster growth and absolute poverty alleviation, although some important counter-examples emerge, especially in Sub-Saharan Africa. While FDIs seem to be neutral in terms of their impact on income distribution and poverty, financial liberalization seems to have adverse effects on relative poverty.

2) Which are the channels through which trade and FDI affect employment, withincountry income distribution and poverty reduction?

The positive outcome of increasing trade on poverty reduction is mediated by increasing economic growth. Since overall trade (import+export) is neutral in terms of income distribution and fosters economic growth, the final outcome is an overall reduction in poverty.

As far as employment and income distribution are concerned, a clear message emerging from many studies is that technology matters. If trade (especially through importation of machinery) and FDI are characterized by labour-saving and skilled-biased technologies, globalization implies consequences which are opposite to the HO/SS predictions, i.e. decreasing employment and increasing within-country income inequality. In this context, the preliminary theoretical and empirical results discussed in Section 4 concerning the spreading of SBTC from developed to middle income DCs - open the way to a very promising avenue of further research.

Another important mediating channel of the social consequences of increasing trade and FDI is the institutional organization of the labour market (including the informal sector). The presence of labour market flexibility and extensive use of informal labour may increase the positive employment impact, in quantitative terms, of globalization. 
However, possible counter-effects are quite serious and negative, and they entail increasing income-inequality and social dumping (a sort of "race to the bottom" and "beggar thy neighbour" race induced by globalization). In the end, this regressive race may imply a substantial reduction in the socio-economic capabilities of a given DC, finally affecting the "absorptive capacity" of that country in terms of political institutions, social cohesion and technological opportunities.

3) What is the role of the level of development and of the institutional framework of a given DC?

On the whole, the level of economic and human development does matter in shaping the direction and the impact of the current wave of globalization. For instance, the role of the physical and human infrastructures within a DC is crucial in maximizing the positive employment and distributional effects of increasing trade and FDI. Conversely, bottlenecks in the supply of educated and skilled labour and in public and private investments (including $\mathrm{R} \& \mathrm{D}$ ) may condemn a country to marginalisation, exploitation and high levels of domestic unemployment and income inequality.

Examples and policy implications are quite straightforward and concern: the role of education and training; the institutions regulating the labour and the capital markets; the modes of "governance" at the local, regional and national levels (including tax reforms and eradicating of corruption); industrial and innovation policies targeting new and fast growing sectors and products; the construction of a welfare system able to create safety nets for possible victims of the globalization process.

4) Given the results from the previous points, what policy suggestions can be made to a globalizing DC?

Needless to say, here we cannot go into a deep analysis of possible national and international policy options; however, we can briefly highlight from the previous discussion four main avenues for policies devoted to amplifying the positive impacts of globalization in terms of a DC's domestic employment and within-country income distribution. 
a) Market failures and disparities in the initial levels of economic and human development, technological "absorptive capacity” and “social capabilities” call for "controlled liberalization" as the best way to foster globalization. Indeed cautious globalizers seem to be characterised by the best employment performances, while faster globalization may imply a wider income inequality trough increasing import. Together with some form of policy controls on trade and FDI, financial liberalization should be even more restrained in particular historical circumstances. In fact, a sudden financial liberalization can be accompanied by increasing vulnerability and increasing poverty.

b) Given the crucial role of the specific institutional, structural and technological characteristics and the uneven distribution of the positive employment effects of globalization (both in terms of countries and in terms of economic sectors), a possible new role emerges for regional, industrial and innovation policies at the national level.

c) Given the possible adverse distributional effect of importing pervasive SBTC, a crucial role has to be attributed to national and local education and training policies, in order to increase the supply of skills. Conversely, skill shortage implies an output constraint and an increasing wage dispersion with negative effects both in terms of domestic employment and within-country income inequality.

d) Heterogeneous and country-specific impacts in terms of employment and income distribution call for preventive intervention (for instance through insurance schemes and/or social safety nets) at the international level by means of adequate social, labour and income multilateral policies. 


\section{References}

- Abramovitz, M. (1986), “Catching-up, Forging Ahead and Falling Behind”, Journal of Economic History, vol.46, pp.385-406.

- Abramovitz, M. (1989),, Thinking about Growth, Cambridge University Press, Cambridge.

- Acemoglu, D. (1998), Why do New Technologies Complement Skills? Directed Technical Change and Wage Inequality, Quarterly Journal of Economics, vol. 113, pp. 1055-89.

- Aitken, B. and A. Harrison (1999), Do Domestic Firms Benefit from Direct Foreign Investment? Evidence from Venezuela, American Economic Review, vol. 89, pp. 60518.

- Barba Navaretti, G., Soloaga, I. and W. Takacs (1998), When Vintage Technology Makes Sense. Matching Imports to Skills, in Working Paper World Bank, n.1923, Washington D.C. 1998.

- Basu, S. and D.N. Weil (1998), Appropriate Technology and Growth, Quarterly Journal of Economics, vol. 113, pp.1025-1054.

- Bayoumi, T., Coe D.T. and E. Helpman, (1999), R\&D Spillovers and Global Growth, in Journal of International Economics, vol. 47, pp.399-428.

- Berg J. and L. Taylor (2001), External Liberalization, Economic Performance, and Social Policy, in Lance Taylor (ed.), External Liberalization, Economic Performance, and Social Policy, Oxford University Press, Oxford, pp. 11-55.

- Berman, E. and Machin, S. (2000), Skill-biased Technology Transfer around the World, Oxford Review of Economic Policy, vol.16, pp.12-22.

- Berman, E. and Machin, S. (2004), Globalization, Skill-Biased Technological Change and Labour Demand, in Lee, E. and M. Vivarelli (eds.), Understanding Globalization, Employment and Poverty Reduction, Palgrave Macmillan, New York, pp. 39-66..

- Bhagwati, J. and T.S. Srinivasan, (2002), “Trade and Poverty in the Poor Countries”, American Economic Review Papers and Proceedings, 92(2): 180-3. 
- Birchenall, J.A., (2001), Income Distribution, Human Capital and Economic Growth in Colombia, Journal of Development Economics, vol. 66, pp.271-287.

- Bowles, Samuel (2001), A Future for Labor in the Global Economy, TIPS Working Paper, n.1, Trade and Industrial Policy Secretariat.

- Cimoli, M. and G. Dosi (1995), Technological Paradigms, Patterns of Learning and Development: An Introductory Roadmap, in “Journal of Evolutionary Economics”, vol 5, pp.243-268.

- Cimoli, M. and Katz, J. (2003), "Structural Reforms, Technological Gaps and Economic Development: a Latin American Perspective”, Industrial and Corporate Change, vol.12, pp.387-411.

- Coe D.T., Helpman E. and A.W. Hoffmaister, (1997), North-South R\&D Spillovers, Economic Journal, vol 107, pp.134-149.

- Collier, P. and Dollar, D. (2002), Globalization, Growth, and Poverty: Building an Inclusive World Economy, World Bank Policy Research Report, Oxford University Press, Oxford.

- Cornia, G. A. (2004), Trade Liberalization, Foreign Direct Investment and Income Inequality, in Lee, E. and M. Vivarelli (eds.), Understanding Globalization, Employment and Poverty Reduction, Palgrave Macmillan, New York, pp. 169-208..

- Davis, Donald R. (1996), Trade Liberalization and Income Distribution, NBER Working Paper no. 5693, National Bureau of Economic Research, Cambridge (Mass.).

- Dollar D. and Kraay, A. (2001a), Growth is Good for the Poor, mimeo, Development Research Group, The World Bank, Washington, March.

- Dollar D. and Kraay, A. (2001b), Trade, Growth and Poverty, mimeo, Development Research Group, The World Bank, Washington, June.

- Dosi, G., Pavitt, K. and Soete, L. (1990), The Economics of Technical Change and International Trade, New York University Press, New York.

- Easterly, W. (2001), “The Lost Decades: Developing Countries’ Stagnation in Spite of Policy Reforms 1980-1998”, Journal of Economic Growth, vol.6, pp.135-157.

- Eaton J. and S.S. Kortum, (2001), Trade in Capital Goods, European Economic Review, vol. 45, pp. 1195-1235. 
- Edwards, S. (1997), Trade Policy, Growth and Income Distribution, American Economic Review Papers and Proceedings, vol.87, pp. 205-10.

- Fagerberg, J. (1988), International Competitiveness, The Economic Journal, vol.98, pp. 355-374.

- Fagerberg, J. (1994), Technology and International Differences in Growth Rates, Journal of Economic Literature, vol. 32, pp. 1147-75.

- Feenstra, R.C. and Hanson G.H. (1996), Foreign Investment, Outsourcing, and Relative Wages, in R.C. Feenstra, G.M. Grossman and D.A. Irwin (eds.), Political Economy of Trade Policy: Essays in Honor of Jagdish Bhagwati, MIT Press, Cambridge (Mass.), pp. 89-127.

- Feenstra, Robert C. and Gordon H. Hanson (1997), Foreign Direct Investment and Relative Wages: Evidence from Mexico’s Maquiladoras, Journal of International Economics, vol. 42, pp. 371-93.

- Findlay, R. (1978), Relative Backwardness, Direct Foreign Investment and Transfer of Technology: A Simple Dynamic Model, Quarterly Journal of Economics, vol. 92, pp. $1-16$.

- Figini, P. and E. Santarelli (2005), Openness, Economic Reforms, and Poverty: Globalization in the Developing Countries, Journal of Developing Areas, forthcoming. - Fosu, A. (2004), The Social Impact of Globalization: The Scope for National Policies, in Lee, E. and M. Vivarelli (eds.), Understanding Globalization, Employment and Poverty Reduction, Palgrave Macmillan, New York, pp. 327-48.

- Ghose, A. K. (2000), Trade Liberalization and Manufacturing Employment, ILO Employment Paper 2000/3, International Labour Office, Geneva.

- Ghose, A. K. (2003), Jobs and Incomes in a Globalizing World, International Labour Office, Geneva.

- Gros, J.B. (2004), Labour Demand of Developing Countries in a Decade of Globalization: A Statistical Insight, in Lee, E. and M. Vivarelli (eds.), Understanding Globalization, Employment and Poverty Reduction, Palgrave Macmillan, New York, pp. 107-39. 
- Grossman, G.M. and Helpman, E. (1991), Innovation and Growth in the Global Economy, MIT Press, Cambridge (Mass.).

- Haddad, M. and A. Harrison (1993), Are there Positive Spillovers from Direct Foreign Investment, Journal of Development Economics, vol. 42, pp.51-74.

- Higgins, Matthew and Jeffrey G. Williamson (1999), Explaining Inequality the World Round: Cohort Size, Kuznets Curves, and Openness, NBER Working Paper no. 7224, National Bureau of Economic Research, Cambridge (Mass.).

- Kaminsky, G.L. and Schmukler, S.L. (2003), Short-run Pain, Long-run Gain: the Effects of Financial Liberalization, NBER Working Paper No. 9787, National Bureau of Economic Research, Cambridge (Mass.).

- Kathuria, V. (2001), Foreign Firms and Technology Transfer Knowledge Spillovers to Indian Manufacturing Firms: A Stochastic Frontier Analysis, Applied Economics, vol 33, pp.625-642.

- Kinoshita, Y. (2000), R\&D and Technology Spillovers via FDI: Innovation and Absorptive Capacity, in William Davidson Institute Working Paper Series, 349, William Davidson Institute at the University of Michigan Business School, Ann Arbor, 2000.

- ILO (2002), “Trade Liberalization and Employment: An Update of the Paper Presented at 282 ${ }^{\text {nd }}$ (November 2001) Session of the Governing Body”, International Labour Office GB.283/WP/SDG/1.

- Lall S. (2004), , The Employment Impact of Globalization in Developing Countries, in Lee, E. and M. Vivarelli (eds.), Understanding Globalization, Employment and Poverty Reduction, Palgrave Macmillan, New York, pp. 73-101.

- Langmore, J. (2004), International Strategy for Decent Work, in Lee, E. and M. Vivarelli (eds.), Understanding Globalization, Employment and Poverty Reduction, Palgrave Macmillan, New York, pp. 349-754.

- Lee, E. (1996), “Globalization and Employment: Is Anxiety Justified?”, International Labour Review, 135 (5): 485-97.

- Lee, E. (1998), The Asian Financial Crisis: The Challenge for Social Policy, International Labour Office, Geneva. 
- Lee, E. (2000), "Globalization and Employment: the New Policy Agenda", Development, vol.43, pp.18-20.

- Lee, E and M. Vivarelli (eds.) (2004), Understanding Globalization, Employment and Poverty Reduction, Palgrave Macmillan, New York.

- Levinsohn, J. (1999), "Employment Responses to International Liberalization in Chile”, Journal of International Economics, 47 (2): 321-44.

- Matusz, S. J. and D. Tarr, (1999), Adjusting to Trade Policy Reform, World Bank Working Paper on International Economics, Trade, Capital Flows, n. 2141, World Bank, Washington D.C.

- Mazumdar, J. (2001), Imported Machinery and Growth in LDCs, Journal of Development Economics, vol. 65, pp.209-224.

- Milanovic, B. (2002a), Can We Discern the Effect of Globalization on Income Distribution? Evidence from Household Budget Surveys, World Bank Policy Research Working Paper No. 2876.

- Milanovic, B. (2002b), The Ricardian Vice: Why Sala-i-Martin Calculations of World Income Inequality Cannot be Right, World Bank, Development Research Group, mimeo.

- Milanovic, B. (2003), The Two Faces Of Globalization: Against Globalization as We Know it, Development and Comp Systems, Economics Working Paper Archive at WUSTL No. 0303007.

- Montobbio, F. and F. Rampa (2005), The Impact of Technology and Structural Change on Export Performance in Nine Developing Countries, World Development, vol 33, pp. 527-547.

- O’Connor, D. and M. R. Lunati (1999), Economic Opening and the Demand for Skills in Developing Countries: A Review of Theory and Evidence, OECD Development Centre Technical Papers no. 149, OECD, Paris.

- Orbeta, A. (2002), “Globalization and Employment: The Impact of Trade on Employment Level and Structure in the Philippines”, Discussion Paper Series (4), Philippine Institute for Development Studies. 
- Pavcnik, N., Blom, A., Goldberg, P. and Schady, N. (2003) Trade Liberalization and Labor Market Adjustment in Brazil." World Bank Working Paper, n.. 2982, World Bank, Washington D.C.

- Perez, C. (1983), "Structural Change and the Assimilation of New Technologies in the Economic and Social System”, Futures, vol.15, pp.357-375.

- Piva, M. (2003), “The Impact of Technology Transfer on Employment and Income Distribution in Developing Countries: a Survey of Theoretical Models and Empirical Studies”, International Labour Office, Policy Integration Department, International Policy Group, Working Paper n.15, Geneva.

- Rama, M. (1994), “The Labour Market and Trade Reform in Manufacturing”, in Michaell Connolly and Jaime de Melo, eds., Essays on the Effects of Protectionism on a Small Country: the Case of Uruguay, The World Bank, Washington D.C.

- Ravallion, M. (2001), “Growth, Inequality and Poverty: Looking Beyond Averages”, World Development, 29(11): 1803-1815.

- Rawski, T. G. (2002), Recent Developments in China’s Labor Economy, International Labour Office, Policy Integration Department, International Policy Group, Working Paper n.11, Geneva.

- Reddy, S. (2004), Globalization, Labour Markets and Social Outcomes in Developing Countries, in Lee, E. and M. Vivarelli (eds.), Understanding Globalization, Employment and Poverty Reduction, Palgrave Macmillan, New York, pp. 309-26..

- Reddy, S.G. and Pogge, T.W. (2002), How Not to Count the Poor, Department of Economics, Barnard College, Columbia University, mimeo.

- Revenga, A. (1997), “Employment and Wage Effects of Trade Liberalization: the Case of Mexican Manufacturing”, Journal of Labour Economics, 15 (3): S20-S43.

- Robbins, D. J. (1996), HOS Hits Facts: Facts Win; Evidence on Trade and Wages in the Developing World, Development Discussion Paper no. 557, Harvard Institute for International Development, Harvard University, Cambridge (Mass.).

- Robbins, D.J. (2002), The Impact of Trade Liberalization Upon Inequality in Developing Countries: A Review of Theory and Evidence, International Labour Office, 
Policy Integration Department, International Policy Group, Working Paper n.13, Geneva.

- Rodriguez, F. and D. Rodrik (1999), Trade Policy and Economic Growth: a Skeptic's Guide to the Cross-national Evidence, NBER Working Paper, No. 7081, Cambridge (Mass.).

- Rodrik, D. (2000), Comments on 'Trade, Growth and Poverty' by D.Dollar and A.Kraay, Cambridge (Mass.), Harvard University, mimeo.

- Saggi, K. (1999), Foreign Direct Investment, Licensing, and Incentives for Innovation, Review of International Economics, vol. 7, pp.699-714.

- Sala-i-Martin, X. (2002), The Disturbing “Rise” of Global Income Inequality, NBER Working Paper No. 8904, National Bureau of Economic Research, Cambridge (Mass.).

- Santarelli, E. and P. Figini (2004), Does Globalization Reduce Poverty? Some Empirical Evidence for the Developing Countries, in Lee, E. and M. Vivarelli (eds.), Understanding Globalization, Employment and Poverty Reduction, Palgrave Macmillan, New York, pp. 247-303.

- Shafaeddin, M. (2005), Trade Policy at the Crossroads: The Recent Experience of Developing Countries, Palgrave Macmillan, New York.

- Spiezia, V. (2004), Trade, Foreign Direct Investment and Employment: Some Empirical Evidence, in Lee, E. and M. Vivarelli (eds.), Understanding Globalization, Employment and Poverty Reduction, Palgrave Macmillan, New York, pp. 143-63..

- Spilimbergo, Antonio, Juan Luis Londono and Miguel Székely (1999), Income Distribution, Factor Endowments, and Trade Openness, Journal of Development Economics, vol. 59, pp. 77-101.

- Stiglitz, J.E. (2002), Globalization and its Discontents, New York: W.W. Norton \& Company.

- Stolper, W.F. and P.A. Samuelson (1941), Protection and Real Wages, Review of Economic Studies, vol. 9, pp.58-73.

- Targetti, F. and A. Foti (1997), , Growth and Productivity: A Model of Cumulative Growth and Catching Up, Cambridge Journal of Economics, vol. 21, pp.27-43. 
- Taylor, L. (2004), External Liberalization in Asia, Post-Socialist Europe and Brazil, in Lee, E. and M. Vivarelli (eds.), Understanding Globalization, Employment and Poverty Reduction, Palgrave Macmillan, New York, pp. 13-34..

- UNCTAD (2002), The Least Developed Countries Report 2002: Escaping the Poverty Trap, United Nations, New York and Geneva.

- UNIDO (2002) Industrial Development Report 2002/2003, Vienna: UNIDO.

- Verspagen, B. and Wakelin, K. (1997), “Trade and Technology from a Schumpeterian Perspective”, International Review of Applied Economics, vol.11, pp.181-194.

- Vivarelli, M. (2004), Globalization, Skills and Within Country Income Inequality in Developing Countries, in Lee, E. and M. Vivarelli (eds.), Understanding Globalization, Employment and Poverty Reduction, Palgrave Macmillan, New York, pp. 211-243.

- Wang, J. Y. and M. Blomstrom (1992), Foreign Investment and Technology Transfer: A Simple Model, European Economic Review, vol. 36, pp. 137-55.

- Winters, A.L. (2000), “Trade, Trade Policy and Poverty: What Are the Links”, London, CEPR Discussion Paper, No. 2382.

- Winters, L.A., McCulloch, N. and A. McKay (2004), Trade Liberalization and Poverty: The Evidecne So Far, Journal of Economic Literature, vol. 42, pp. 72-115.

- Wood, A. (1994), North-South Trade, Employment and Inequality. Changing Fortunes in a Skill-Driven World, Clarendon Press, Oxford.

- Wood, A. (1997), Opennesss and Wage Inequality in Developing countries: The Latin American Challenge to East Asian Conventional Wisdom, The World Bank Economic Review, vol.11, pp. 33-57.

- Wood, A. and C. Ridao-Cano (1999), Skill, Trade and International Inequality, Oxford Economic Papers, vol. 51, pp. 89-119.

- Xu, B. and J. Wang (2000), Trade, FDI, and International Technology Diffusion, Journal of Economic Integration, vol. 15, pp.585-601.

- Zhu, S. C. and D. Trefler (2001), Ginis in General Equilibrium: Trade, Technology and Southern Inequality, NBER Working Paper no. 8446, National Bureau of Economic Research, Cambridge (Mass.). 